\title{
Analysis Quality of Environmental Health in Coastal Communities
}

\author{
Sri Malem Indirawati ${ }^{1,2}$ Setiaty Pandia ${ }^{3}$ Herman Mawengkang ${ }^{4}$ Wirsal Hasan ${ }^{5}$ \\ ${ }^{1}$ Study Program of Natural Resource and Environmental Management, Graduate School, University of Sumatera Utara, \\ and ${ }^{2}$ STIKES SUMUT, Indonesia \\ srimalem_indirawati@yahoo.co.id \\ ${ }^{3}$ Department of Chemistry Engineering, Faculty of Engineering, University of Sumatera Utara, Indonesia \\ setiaty_pandia@yahoo.com \\ ${ }^{4}$ Department of Mathematics, Faculty of Mathematics and Natural Sciences, University of Sumatera Utara, Indonesia \\ hmawengkang@yahoo.com \\ ${ }^{5}$ Department of Public Health, Faculty of Public Health in University Of Sumatera Utara, Indonesia \\ wirsal_hasan@yahoo.com
}

\begin{abstract}
Health quality of the coastal environment is very critical due to sea water pollution by industrial waste, ports, marine transportation, domestic waste and community activities. Sea water pollution will have an impact on the environment, especially community water resources. Pollutants such as heavy metals pose a threat to public health. This study aims to analyze the quality of the environment and to measure the magnitude of environmental health risks in coastal communities. This is quantitative research that analyzes the concentration of heavy metals in the coastal and public health at risk. Sample subject is the community who use bore well and the sample of the object is bore well around Belawan and sea water. Methods used for analyzing the concentration of $\mathrm{Pb}$ and $\mathrm{Cd}$ is $\mathrm{AAS}$ (Atomic Absorbstion Spectrophotometer), environmental health risks is measured by the EHRA (environmental Health Risks Assessment) method.

The Results is $\mathbf{P b}$ concentration average in marine is $\mathbf{0 . 0 5 2}$ $\mathrm{mg} / \mathrm{l}$ and $\mathrm{Cd}$ is $0.004 \mathrm{mg} / \mathrm{l}$. $\mathrm{Pb}$ concentration in drinking water with an average $0,002 \mathrm{mg} / \mathrm{l}$ and $\mathrm{Cd}$ is $0.001 \mathrm{mg} / \mathrm{l}$, the amount of health risks RQ $<1$. Public complaints found were digestive disorders, skin diseases, headaches, arthritis etc. Environmental management by implementing risk management of health needs to be done in an effort to minimize contamination of $\mathrm{Pb}$ and $\mathrm{Cd}$ in coastal areas of Belawan.
\end{abstract}

Keywords - $\mathrm{Pb}$ and $\mathrm{Cd}$, sea water, drinking water, health risks

\section{INTRODUCTION}

Major cities in Indonesia are generally located in coastal areas, the characteristics of coastal areas with characteristics towards the land affected by the physical properties of the ocean such as tidal, wind, wave and intrusion and seaward influenced by natural processes on land such as sedimentation, the flow of fresh water from the stream watersheds, domestic sewage, industrial and agricultural. Environmental pollution in coastal areas make the waters along the shoreline and the beach itself becomes unfit for use by the general public and has become a global health problem [1].

Health quality of the coastal environment is very critical due to sea water pollution by industrial waste, ports, marine transportation, domestic waste and community activities. Polluted sea will have an impact on the environment, especially the quality of community water sources. Belawan is a coastal area in Medan city, heavy metal pollution has taken place in the region's waters of Belawan, as in previous studies which found marine life that has been contaminated with heavy metals $\mathrm{Pb}, \mathrm{Cd}$ and $\mathrm{Cr}[2]$.

Heavy metals are elements that are not degradable (persistent) and can accumulate through the food chain (bioaccumulation), with long-term adverse effects to living beings and can spread far from the original source [3]. heavy metals are very harmful to human health because it cannot be destroyed by microorganisms and accumulates in the environment, especially the water-component parts by forming complex compounds together with inorganic and organic compounds by adsorption and combined [4].

$\mathrm{Pb}$ is neurotoxic which can accumulate in the body, $\mathrm{Pb}$ high in the body causing disorders of hemoglobin synthesis of blood, neurological disorders (nervous), disorders of the kidneys, the reproductive system, acute or chronic nervous 
system, and impaired function of the lungs. In addition, it can lower the IQ of young children if there are 10-20 $\mu \mathrm{gr} / \mathrm{dl}$ in the blood, every increase of $10 \mu \mathrm{gr} / \mathrm{dl}$ in the blood would reduce IQ by 4 points [5].

Cadmium is a silvery white metal, soft, shiny, insoluble in alkaline, easy action and produce oxides when heated [6]. Cadmium is a metal which when taken into the body will settle and accumulate in certain time which caused damage, not only on the bones and kidneys but also testis, heart, liver, brain and blood system. Cadmium accumulated in the long term can inhibit the action of the lungs, and even lead to lung cancer, nausea, vomiting, diarrhea, cramps, anemia, dermatitis, slow growth, kidney and liver damage, and cardiovascular disorders. Cadmium can also damage bones (osteomalacia, osteoporosis) and increased blood pressure. Cadmium poisoning Common symptoms are pain in the chest, shortness of breath (short), cough, and weakness [7].

Another phenomenon the location of this study has been found $\mathrm{Pb}$ and $\mathrm{Cd}$ of freshwater resources of the communities living in coastal areas. Seawater intrusion is suspected as the primary cause in which there has been a process of sea level rise that sea water into the wells of the population. Medan based research [8] states in Belawan sea water intrusion has reached $13 \mathrm{Km}$ of coastline. Seawater intrusion assumed that it could cause heavy metal pollution of freshwater resources population that is shallow wells and deep wells. Belawan coastal Presence of heavy metals $\mathrm{Pb}, \mathrm{As}$ and $\mathrm{Mn}$ in drinking water cause effects on the health effects, especially in infants of pregnant women who consume water that has been contaminated with heavy metals [9]. Research on the risk of consuming contaminated drinking water in Kohistan, North Pakistan in measuring the risk of contamination of $\mathrm{Cu}, \mathrm{Co}, \mathrm{Cr}$, $\mathrm{Mn}, \mathrm{Ni}, \mathrm{Pb}, \mathrm{Zn}$ and $\mathrm{Cd}$ in drinking water of the population. The pollution comes from activities geogenik the process of weathering, erosion and anthropogenic activities are mining, industrial waste, domestic and agriculture [10] communities still exist that utilize the artesian well water as a source of drinking water [10].

Pollutants such as heavy metals pose a threat to the health of coastal communities, especially
Belawan, seawater intrusion phenomenon allows community water sources polluted by heavy metals. People who use the water as drinking water in particular will be exposed to heavy metals contained in their drinking water. Further studies can be done is to analyze the risk in people who consume drinking water sourced from clean water from wells in coastal areas.

Studies of environmental health risk analysis is one method of study environmental effects on health. This method is very suitable for the study of environmental impact on public health in the Environmental Impact Assessment is being able to predict the risk of exposure by the projection period ahead. Enviromental health Risks Assesment (EHRA) consists of four stages of assessment, namely hazard identification, dose-response analysis, exposure analysis and risk characterization. These measures should not be done sequentially, unless the risk characterization as the last stage [11]. The study method is the result of research EHRA exposure to arsenic in drinking water in Bangladesh society cause of death based on the study cohort [12].

The phenomenon of environmental quality in coastal Belawan pollution source of some concern to human activities cause pollution both at sea and on community water sources. This condition if it continues to be an impact on public health. Based on these studies will be needed to analyze the presence of heavy metals in the coastal environment and quantify health risks in people who are exposed to heavy metals.

\section{METHOD}

This study is a quantitative study is to analyze the levels of heavy metals in the coastal environment is by measuring the levels of $\mathrm{Pb}$ and $\mathrm{Cd}$ in the waters, $\mathrm{Pb}$ and $\mathrm{Cd}$ in drinking water sources and the population large measure on the public health risks. The sample was seawater, drinking water that comes from borewell and the people who live in coastal consume drinking water from the source of the borewell. The data analysis research variables are as follows:

a. Seawater samples taken 3 points in the territorial waters of the subdistrict of Medan Belawan, Parameters measured were physical quality (odor, taste, clarity), 
chemical (temperature, DO, BOD and $\mathrm{PH}, \mathrm{Cd}, \mathrm{Hg}, \mathrm{Ar}$, $\mathrm{Pb}$ ), and biology then the results were compared with $\mathrm{LH}$ Decree No. 51 of 2004 regarding marine water quality standards.

b. Samples of drinking water taken from wells drilled in the study site there are a number of 89 samples of the wellbore, the determination of sampling wells with a random sampling of a number of parameters measured is the concentration of $\mathrm{Cd}$ and $\mathrm{Pb}$ in drinking water The results are then compared with Minister Regulation Number 492 / Menkes / 2010 on drinking water quality requirements. $\mathrm{NAB}$ 0:01 $\mathrm{Pb} \mathrm{mg} / \mathrm{L}, \mathrm{Cd} 0.003 \mathrm{mg}$ / L.

c. Analysis of environmental health risks conducted the analysis stage of exposure, dose response analysis, risk characterization and risk management. ARKL method by measuring the variables of the public to sample analysis stage exposure is measured variable; concentration of drinking water consumed $(\mathrm{mg} / \mathrm{l})$, the rate of intake (1/ day), weight $(\mathrm{kg})$, the duration of exposure (years), the time period average (Dt x 365 days) all these variables to measure Intake (intake). This is described in the equation below

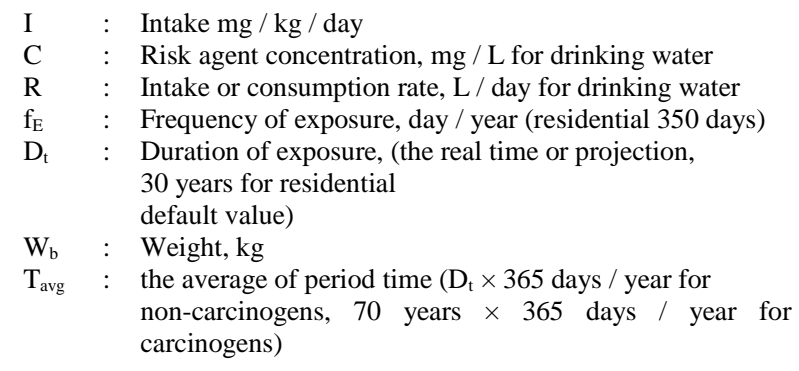

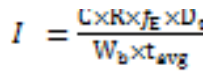

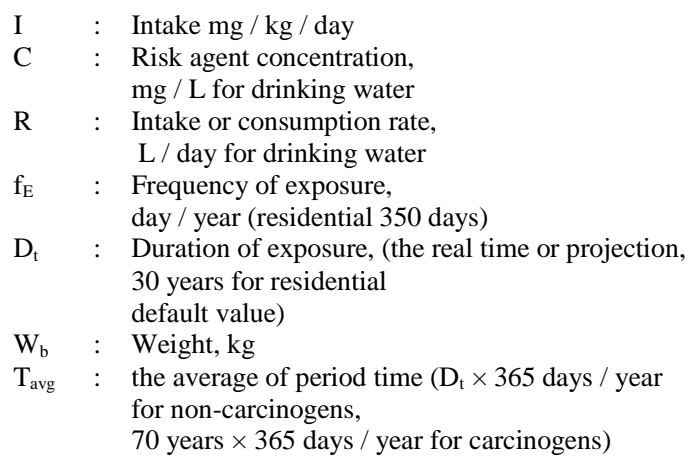

Reference Doses of $\mathrm{Pb}(R f D \mathrm{~Pb})=4 \times 10^{-3}$

$R f D$ Cd $=5 \times 10^{-4}$

\section{RESULT AND DISCUSSION}

\section{A. $\mathrm{Pb}$ and $\mathrm{Cd}$ Concentration in The Seawater}

Based on laboratory test results to the results obtained tidal conditions and Cadmium $\mathrm{Pb}$ concentration is above the quality standard of value, this means has been heavily polluted coastal waters as well as with the valence of chromium 6 and nitrates also exceeded the quality standard. Suspected pollution sources come from domestic sewage, industrial and harbor. This location has 8 major industries, 15 industries and 32 small home industries.

TABLE I

PB ANd CD Concentration In The SEAWATER

\begin{tabular}{|c|c|c|c|c|c|}
\hline Sample Location & \begin{tabular}{|l|}
$\mathrm{Cd}(\mathrm{mg} / \mathrm{l})$ \\
$\mathrm{TLV}$ \\
$=0.002$ \\
\end{tabular} & $\begin{array}{l}\mathrm{Pb}(\mathrm{mg} / \mathrm{l}) \\
\mathrm{TLV} \\
=0.005\end{array}$ & $\begin{array}{|lr|}\mathrm{Cr} & \text { val6 } \\
(\mathrm{mg} / \mathrm{l}) & \\
\mathrm{TLV}= & 0.002 \\
\end{array}$ & \begin{tabular}{|ll}
$\mathrm{PH}$ & \\
7 & - \\
8.5 & \\
\end{tabular} & \begin{tabular}{|l|} 
DO \\
Min \\
5 \\
\end{tabular} \\
\hline $\begin{array}{l}\text { MEDAN } \\
\text { BELAWAN }\end{array}$ & \multicolumn{4}{|c|}{ TIDE } & \\
\hline $\begin{array}{c}1 . \mathrm{N} 03.79010 \\
\text { E } 098.69701\end{array}$ & 0.0062 & 0.064 & 0.019 & 7.6 & 5.0 \\
\hline $\begin{array}{c}\text { 2. N } 03.78963 \\
\text { E } 098.68475\end{array}$ & 0.0054 & 0.032 & 0.021 & \begin{tabular}{|l|l}
6.8 \\
\end{tabular} & 5.03 \\
\hline $\begin{array}{l}\text { 3. N } 03.78898 \\
\text { E } 098.67907 \\
\end{array}$ & 0.0032 & 0.060 & 0.022 & 6.6 & 4.77 \\
\hline \multirow[t]{2}{*}{ Mean: } & \begin{tabular}{|l|}
0.0042 \\
\end{tabular} & 0.052 & 0.020 & 7.0 & 4.93 \\
\hline & \multicolumn{5}{|c|}{ LOW TIDE } \\
\hline $\begin{array}{l}\text { 1.N } 03.7901^{0} \\
\text { E } 098.69701^{0}\end{array}$ & 0.001 & 0.056 & 0.017 & 8.5 & 8.0 \\
\hline $\begin{array}{l}\text { 2. N } 03.78963^{0} \\
\mathrm{E} 098.68475^{0}\end{array}$ & 0.0017 & 0.063 & 0.019 & 8.2 & 9.1 \\
\hline $\begin{array}{l}\text { 3. N } 03.78898^{0} \\
\text { E } 098.67907^{\circ}\end{array}$ & 0.0021 & 0.053 & 0.021 & 8.1 & 7.9 \\
\hline Mean: & 0.0016 & 0.057 & 0.019 & 8.26 & 8.3 \\
\hline
\end{tabular}

\section{B. Metal Pollution in Borewells}

The measurement results Sample some 89 boreholes used by the people as the main source of drinking water in the obtained results mean $\mathrm{Pb}$ concentration is $0.0045 \mathrm{mg} / \mathrm{l}$, with a value of Standard Deviation (SD) $=0057$ and a maximum value of $0.026 \mathrm{mg} / 1$. There are a number of 13 (14.6\%) drilled wells have concentrations of $\mathrm{Pb}$ exceeds the threshold limit value, Threshold Limit Values for $\mathrm{Pb}$ based Permenkes RI. No. 429 / Menkes / PER / IV / $20100.01 \mathrm{mg} / \mathrm{L}$.

$\mathrm{Cd}$ concentration in the wellbore is still below the threshold value, the value of the average concentration of $0.001 \mathrm{mg} / 1, \mathrm{SD} 0.0006 \mathrm{mg} / 1$ and a maximum value of $0.0028 \mathrm{mg} / 1 . \mathrm{Cd}$ concentration was still below the threshold value is $0.005 \mathrm{mg} / 1$. Pollutant sources are assumed waters, seawater intrusion factor as originator of the contamination of the wellbore which is used by the people as a source of drinking water. Sea water intrusion in the city of Medan had reached $13 \mathrm{Km}$ ${ }^{[8]}$ and the results of the health center reports there are some $48.7 \%$ reported unhealthy home, wastewater disposal systems directly into the sea. 
Results table below describes the characteristics of the wellbore includes Distance wells from pollution sources are assumed to be water, depth, age of the wellbore and the concentration of $\mathrm{Pb}$ and $\mathrm{Cd}$ in drinking water of the population.

TABLE II

CHARACTERISTIC DisTRIBUTION OF BOREWELL

\begin{tabular}{|c|c|c|c|c|c|}
\hline Characteristic & $\mathbf{N}$ & Minimum & Maximum & Mean & SD \\
\hline Distance & 89 & 1.2 & 462 & 144.37 & 121.64 \\
\hline Depth & 89 & 66 & 180 & 94.43 & 17.84 \\
\hline $\mathrm{Pb}$ Concentration & 89 & 0.0005 & 0.026 & 0.004 & 0.005 \\
\hline $\mathrm{Cd}$ Concentration & 89 & 0.00004 & 0.004 & 0.0013 & 0.001 \\
\hline
\end{tabular}

\section{Enviromental Health Risks Assesement}

A total of 34 respondents consume drinking water that has been contaminated with $\mathrm{Pb}$, but poses no risk of this can be explained from the calculation analysis of health risks from exposure to lead in drinking water such as in the results table below. Results The mean RQ $=0: 04, \mathrm{RQ}=0.020$ minimum value, maximum value 0325 with $\mathrm{SD}=$ $0: 52$. The magnitude of health risks (RQ) is still under one $(R Q<1)$ This means that at the time of the study there is no health risk, meaning $\mathrm{Pb}$ in drinking water that are resident at the time of measurement do not pose a risk despite being polluted. $\mathrm{Pb}$ heavy metal is said to be very dangerous to human health that cannot be destroyed by microorganisms and accumulates in the environment, especially the water-component parts to form a complex compound together with the organic and inorganic compounds by adsorption and combined [14].

The results of the samples of underground water in Bagjata India with resources obtained mining waste contamination $\mathrm{Pb}$ levels in drinking water sources $0.028 \mathrm{mg} / 1$ with RQ) <1 [14]. Although the RQ $<1$ but the exposure will take place throughout the period, the nature of $\mathrm{Pb}$ in the body accumulate and accumulate currently not at risk, but a few years later is likely to cause health effects for society. Symptoms of lead poisoning in the community such as abdominal pain, nausea, diarrhea, neuropaty peripheral nerves, muscle weakness, hands and feet, headaches, depression and anemia.
TABLE III

Result of Risk Assesment Analysis and Risk Quation Of Pb

\begin{tabular}{|c|c|c|c|c|c|}
\hline Variable & Mean & Median & Min & Max & SD \\
\hline $\begin{array}{l}\text { Concentration } \\
\text { (C) } \mathrm{mg} / \mathrm{L}\end{array}$ & 0.0045 & 0.0025 & 0.0054 & 0.026 & 0.056 \\
\hline $\begin{array}{c}\text { Consumption Rate (R), } \\
\text { L/day }\end{array}$ & 1.8795 & 2.0 & 1 & 5 & 0.69 \\
\hline $\begin{array}{c}\text { Frequency of exposure }\left(\mathrm{f}_{\mathrm{E}}\right) \\
\text { day / year }\end{array}$ & 323 & 350 & 48 & 350 & 59.56 \\
\hline $\begin{array}{l}\text { Duration of exposure } \\
\text { (Dt) in year }\end{array}$ & 23.2 & 20.0 & 1 & 70 & 15.96 \\
\hline Weight $\left(\mathrm{W}_{\mathrm{b}}\right), \mathrm{Kg}$ & 56.38 & 59.00 & 20 & 94 & 16.065 \\
\hline $\begin{array}{l}T_{\text {avg }} \text { the average of period } \\
\text { time }\left(D_{t} \times 365 \text { days } / \text { year }\right. \\
\text { for non-carcinogens }\end{array}$ & 8470 & 7300 & 365 & 25550 & 5826 \\
\hline Intake (I) & $8 \times{ }_{5} 10^{-}$ & $5 \times 10^{-5}$ & $5 \times 610^{-}$ & $\begin{array}{l}5 \mathrm{x} \\
10^{-4}\end{array}$ & $\begin{array}{l}8.7 \mathrm{x} \\
10^{-5}\end{array}$ \\
\hline RQ Pb & 0.0419 & 0.0241 & 0.02 & 0.325 & 0.525 \\
\hline
\end{tabular}

In Table 4 below the maximum value for $\mathrm{Cd} 0.78 \mathrm{RQ}$ (RQ <1), this means that the content of cadmium in drinking water do not pose a risk community at the time of measurement lasts. Similarly, the risk $\mathrm{Pb}$ at the time of measurement, but still there is no guard against for the foreseeable future.

TABLE IV

Result of Risk Assesment Analysis and Risk Quation Of Cd

\begin{tabular}{|c|c|c|c|c|c|}
\hline Variable & Mean & Median & Min & Max & SD \\
\hline $\begin{array}{l}\text { Concentration } \\
\text { (C) } \mathrm{mg} / \mathrm{L}\end{array}$ & 0.00127 & 0.0013 & 0.00004 & 0.005 & 0.0007 \\
\hline $\begin{array}{l}\text { Consumption Rate } \\
\text { (R), L/day }\end{array}$ & 1.8795 & 2.0000 & 1 & 5 & 0.69 \\
\hline $\begin{array}{c}\text { Frequency of exposure } \\
\left(\mathrm{f}_{\mathrm{E}}\right) \\
\text { day / year }\end{array}$ & 323 & 350 & 48 & 350 & 59.56 \\
\hline $\begin{array}{l}\text { Duration of exposure } \\
\text { (Dt) in year }\end{array}$ & 23.2 & 20.0 & 1 & 70 & 15.96 \\
\hline Weight $\left(\mathrm{W}_{\mathrm{b}}\right), \mathrm{Kg}$ & 56.38 & 59.00 & 20 & 94 & 16.065 \\
\hline $\begin{array}{c}\mathrm{T}_{\text {avg }} \text { the average of } \\
\text { period time }\left(\mathrm{D}_{\mathrm{t}} \times 365\right. \\
\text { days / year } \\
\text { for non-carcinogens }\end{array}$ & 8470 & 7300 & 365 & 25550 & 5826 \\
\hline Intake (I) & $\begin{array}{c}4.8 \times 10^{-} \\
5\end{array}$ & $\begin{array}{c}4.1 \\
\times 10^{-5}\end{array}$ & $\underset{7}{7.1 \times 10^{-}}$ & $\begin{array}{c}3.9 \times 10^{-} \\
4\end{array}$ & $\begin{array}{c}4.3 \times 10^{-} \\
5\end{array}$ \\
\hline RQ Cd & 0.097 & 0.082 & 0.001 & 0.781 & 0.086 \\
\hline
\end{tabular}

The results showed that the borewells of community werenot contaminated based on the calculation of the environmental health risk analysis (EHRA) was obtained RQ $<1$. This means that the presence of $\mathrm{Cd}$ in drinking water has no health risk to community. RQ is not only depending on the concentration of $\mathrm{Cd}$ in drinking water, the amount 
of consumption per day; weight and length of stay also play a role. Maximum consumption $4 \mathrm{~L}$ per day not show a health risk with maximum RQ = 0,781 . Nevertheless, the nature of $\mathrm{Cd}$ accumulates in the body, if the content of $\mathrm{Cd}$ in drinking water has exceeded the NAB (Permenkes 492 in 2010) feared for a long time will have an impact on health. However, any dose above zero is always has effect.

The sources of $\mathrm{Cd}$ pollution in humans not through consumption of oral only, but can also by air (inhalation) and through the skin. Cadmium is a heavy metal elements which are not needed by the body and toxic.

\section{CONCLUSION}

$\mathrm{Pb}$ concentration average in marine is $0.052 \mathrm{mg} / \mathrm{l}$ and $\mathrm{Cd}$ concetration average is $0.004 \mathrm{mg} / \mathrm{l} . \mathrm{Pb}$ concentration in drinking water with an average $0,002 \mathrm{mg} / \mathrm{l}$ and Cd levels in drinking water with a mean of $0.001 \mathrm{mg} / \mathrm{l}$ and the amount of health risks RQ <1. Public complaints found were digestive disorders, skin diseases, headaches, arthritis and so on. Environmental management by implementing risk management of health needs to be done in an effort to minimize contamination of $\mathrm{Pb}$ and $\mathrm{Cd}$ in coastal areas Belawan so the quality of health of the coastal environment can be improved.

\section{ACKNOWLEDGEMENTS}

I would like to extend my sincere gratitude to the chairman of STIKES Sumatera Utara, respondents and my family who in their own way have given various help for my study.

\section{REFERENCES}

[1] April Clark, Health hazards due to pollution of waters along the coast of Visakhapatnam, east coast of India. Ecotoxicology and Environmental Safety Volume 56, Issue 3: Pages 390-397.2003

[2] Siagian, L. "Pengaruh Pencemaran Logam Berat, $\mathrm{Pb}, \mathrm{Cd}, \mathrm{Cr}$ Terhadap Biota Laut Dan Konsumennya di Kelurahan Bagan Deli Belawan".2008. http://www.usu.Library:Perpustakaan Universitas Sumatera Utara.ac.id, diakses tanggal 4 Agustus 2016

[3] Azhar, H.,Widowati, I \& Suprijanto,J. "Studi Kandungan Logam Berat $\mathrm{Pb}, \mathrm{Cu}, \mathrm{Cd}, \mathrm{Cr}$ pada kerang Simping (Amusium Pleuronectes), Air dan Sedimen Di Perairan Wadung, Demak Serta Analisis Maksimum Tolerable Intake Pada Manusia”. 2012.

[4] Jerrold B., Leikin,M. Frank P. Palouce. P."Poisoning and Toxicology Handbook". Fourth Edition ed.New Yok: Informa Healthcare USA,Inc. 2008

[5] Palar, H. "Pencemaran dan Toksikologi Logam Berat". Rineka Cipta Jakarta. 2004

[6] Widowati, W." Efek Toksik Logam, Pencegahan dan Penanggulangan", Jakarta, Penerbit Andi. 2008

[7] Nordberg FG,Fowler BA, Nordberg M, Fridberg, "Cadmium". In

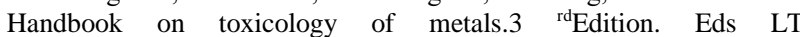
Elsevier,publisher, Amsterdam,; pp445-487. 2007.

[8] Zaldy S. "Analisis Intrusi Air Laut dan Zona Klorida pada Sumur Bor Dalam dan Dangkal di Kawasan Kota Medan dan Sekitarnya". Tesis PSL USU. 2009

[9] Rodigues. "Neurodevelopmental outcomes among 2- to 3-year-old children in Bangladesh with elevated blood lead and exposure to arsenic and manganese in drinking water". Enviromental Health Journal 1:2-9.2016

[10] Said,M , Thahir S.M, Khan S. Health risk assessment of heavy metals and their source apportionment in drinking water of Kohistan region northern Pakistan. 2011. Microchemical Journal 98:334- 343 journal homepage: www.elsevier.com/ locate/microc

[11] IPCS. Environmental Health Criteria XXX: Principles for modelling dose-response for the risk assessment of chemicals (Draft). Geneva: World Health Organization and International Programme on Chemical Safety.2004

[12] Argos M, Karla T, Rathouz PJ. "Arsenic exposure from drinking water, and all cause and chronic-disease mortalities in Bangladesh (HEALS): a prospective cohort study". Lancet 2010; 376: 252-5. 2010

[13] US EPA. Integreted risk information system (IRIS).US EPA,office of Research and Development, National Center for Enviromental Assessment.2006

[14] Jerrold B., Leikin,M. Frank P. Palouce.. P.2008. "Poisoning and Toxicology Handbook". Fourth Edition ed.New Yok: Informa Healthcare USA,Inc 